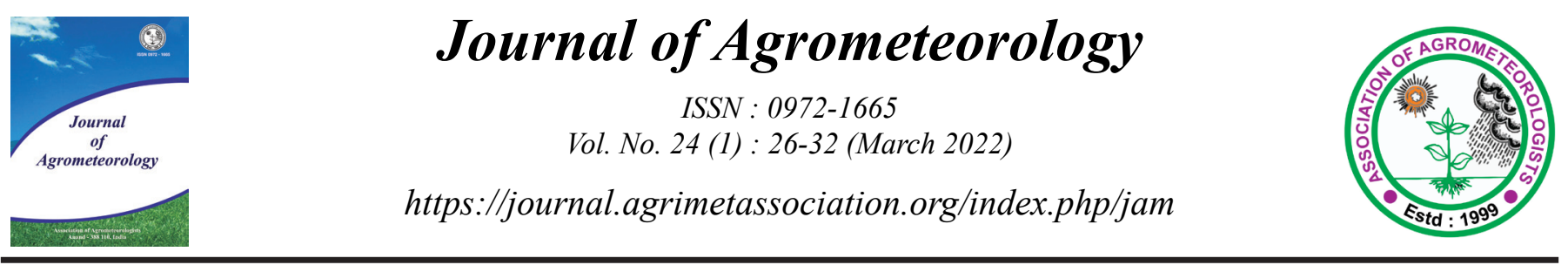

Research Paper

\title{
Influence of weather and nutrients (FYM, N and P) on RGR, LAD, NAR and CGR to determine the productivity of maize, wheat and green gram in a cropping system
}

\section{ALIMAMY KAMARA ${ }^{1}$, S. NARESH KUMAR ${ }^{1 *}$, RAMESH HARIT ${ }^{1}$, MANOJ SHRIVASTAVA ${ }^{1}$, BIDISHA CHAKRABARTI ${ }^{1}$ and KALIKINKAR BANDYOPADHYAY ${ }^{2}$}

\author{
${ }^{I}$ Centre for Environment Science and Climate Resilient Agriculture, ICAR-IARI, New Delhi, India \\ ${ }^{2}$ Division of Agricultural Physics, ICAR-IARI, New Delhi, India \\ "Corresponding author email : nareshkumar.soora@gmail.com
}

\begin{abstract}
In a field experiment, conducted during 2018-19 and 2019-20 at the Research Farm, ICAR-Indian Agricultural Research Institute, New Delhi, factorial combinations of two levels of FYM $\left(0,10 \mathrm{Mg} \mathrm{ha}^{-1}\right)$ applied to maize; four levels of nitrogen $\left(0,60,120,180 \mathrm{~kg} \mathrm{~N} \mathrm{ha}^{-1}\right)$ and three levels of phosphorus $\left(0,30,60 \mathrm{~kg} \mathrm{P}_{2} \mathrm{O}_{5}\right.$ ha $\left.{ }^{-1}\right)$ applied to both maize and wheat and subsequent residual effects on green gram were compared. The RGR was at peak in maize at $29^{\circ} \mathrm{C}$ and in wheat at $12-13^{\circ} \mathrm{C}$. Integral of LAD and incidental solar radiation has significantly improved CGR. The LAD and CGR also shown significant relationship with grain/ seed yield in all the three crops. Slightly higher NAR in combination with LAD and SRD can significantly contribute to overall performance of crops. Results indicated that variation in yield across years due to weather fluctuations, irrespective of treatments, was about 16.7 per cent in maize (kharif), 7.93 per cent in wheat (rabi) and 16.8 per cent in green gram (summer).
\end{abstract}

Key words: Cropping system, growth analysis, weather, maize, wheat, green gram

Plant growth analysis is the method of estimating net photosynthetic production and ability of plants to produce the dry matter. The plant growth analysis, though is based on very basic parameters, is a powerful approach to compare the crop performance across seasons or across species. The analysis provides the insights into the integrated response of crop(s) to the external factors. Growth performance and yield of crops is largely attributed to the influence of climatic factors and nutrient supply, under no water stress conditions. Wheat crop having opportunity to intercept light for longer period was reported to have better growth and yield performance (Mishra et al., 2015; Mukherjee et al., 2020). The LAD, CGR and RGR are positively correlated with biomass and seed yield (Özalkan et al., 2010). The optimum leaf area index and solar radiation interception have positively correlated with maize yield (Kar and Kumar, 2016). Hence, crops should have enough leaf area, its persistence and use efficiency to eventually produce yield. For this, supply of balanced nutrients is important as weather and nutrients significantly influence the growth and yield of crops across seasons and years (Naresh Kumar and Singh, 2000).
Maize (Zea mays), wheat (Triticum aestivum L.) and green gram (Vigna radiata (L.) Wilczek) are important cereal and pulse crops fit in a cropping system. Organic and inorganic nutrients are crucial resources for crop production (Hazra et al., 2019) and supplying farm yard manure (FYM) in every season improved growth and yield of wheat over single season application (Kavinder et al., 2019). The performance of maize and wheat increased with increasing organic and inorganic fertilizer rates until the optimum levels (Tovihoudji et al., 2019). Increasing $\mathrm{N}$ levels (0 to $180 \mathrm{~kg} \mathrm{ha}^{-}$ ${ }^{1}$ ) increased growth and yield of wheat, and had significant residual effect on the growth of succeeding green gram (Shekhawat and Shivay, 2012). Though many studies have been conducted on plant growth analysis while linking with a few external factors, such an analysis is very scarce for cropping systems. Moreover, information about the interaction effect of organic and inorganic fertilizers on plant growth analysis parameters such as leaf area duration in conjunction with intercepted light levels on maize, wheat and green gram cropping system is lacking. The study aims to find the direct effects of nutrients, weather parameters and intercepted light on the growth analysis parameters and their relationship with yield of

Article info - DOI: https://doi.org/10.54386/jam.v24i1.779

Received: 18 August 2021; Accepted: 29 December 2021; Published online: 11 February 2022

This work is licenced under a Creative Common Attribution 4.0 International licence@Author(s), Publishing right @ Association of Agrometeorologists 
maize and wheat crops and the succeeding green gram.

\section{MATERIALS AND METHODS}

The study was conducted during 2018-19 and 201920 growing seasons at the Research Facility of ICAR-Indian Agricultural Research Institute, New Delhi $\left(28.08^{\circ} \mathrm{N}\right.$ latitude, $77.12^{\circ} \mathrm{E}$ longitude and 228.6 metres above mean sea level altitude). The climate of the area is semi-arid with warm summers and mild winters. The soil of the experimental site was classified as sandy loam. The top $30 \mathrm{~cm}$ soil at the initiation of the experiment had moderate $(0.5 \%)$ organic carbon content, with low available nitrogen $\left(187.3 \mathrm{~kg} \mathrm{ha}^{-1}\right)$ and potassium (129 kg ha-1), and with phosphorus level of $25.9 \mathrm{~kg} \mathrm{ha}^{-1}$. The soil was slightly alkaline $(\mathrm{pH} 8.3)$ and non-saline $\left(324 \mu \mathrm{S} \mathrm{cm}^{-1}\right)$ in reaction.

The experiment was conducted in a factorial randomised block design (RBD) with three replications for two years. The factors were FYM, N and P fertilizers. Each treatment had a net plot size of $32 \mathrm{~m}^{2}$. The following crop varieties: maize - Maharaja, wheat - HD 3086 and green gram - Pusa Vishal were sown at seed rate of 25, 110, and $18 \mathrm{~kg} \mathrm{ha}^{-1}$ respectively. Maize was grown during monsoon season (sowing: $27^{\text {th }}$ June, 2018 and $26^{\text {th }}$ July, 2019; harvested in October), wheat was grown in winter season (sowing: $24^{\text {th }}$ November, 2018 and $25^{\text {th }}$ November, 2019; harvested in April) and then green gram in summer season (sowing: $1^{\text {st }}$ May, 2019 and $5^{\text {th }}$ May, 2020; harvested in July) in a cropping system mode. All agronomic practices including hoeing, irrigation, etc., were uniformly carried out to each plot.

The treatments comprised of two levels of FYM (F0 and F10 Mg ha-1), four levels of $\mathrm{N}\left(0,60,120,180 \mathrm{~kg} \mathrm{ha}^{-1}\right)$ fertilizer as urea and three levels of P $\left(0,30,60 \mathrm{~kg} \mathrm{ha}^{-1}\right)$ as SSP in 24 different combinations. Well decomposed FYM was uniformly mixed with soil during land preparation for monsoon season crop (maize). Full dose of $\mathrm{P}$ and 50 per cent of $\mathrm{N}$, was given as basal application. Remaining $\mathrm{N}$ was given in two splits of $25 \%$ each as top dressing at 30 days after sowing, (DAS) and 52 DAS in maize and 30 and 87 DAS in wheat. FYM was not applied to wheat, and none of the fertilizers was applied to greengram.

During the crop growing seasons (June 2018 to July 2020), the daily weather data was collected on parameters such as temperature (minimum and maximum), rainfall, sun-shine duration, relative humidity (minimum and maximum) and wind speed from the IARI weather station. Monthly maximum and minimum temperatures ranged between 17.8 and $40.7^{\circ} \mathrm{C}$ and 5.0 and $28.5^{\circ} \mathrm{C}$, respectively. The highest monthly rainfall $(370.8 \mathrm{~mm})$ was received during July of 2018 and with a total rainfall of $1126.3 \mathrm{~mm}$ and 998.6 mm during 2018-19 and 2019-20 crop cycles, respectively. The corresponding solar radiation during these periods ranged from 5.6 to $29.0 \mathrm{MJ} \mathrm{m}^{-2}$ day $^{-1}$ and 5.7 to $29.8 \mathrm{MJ} \mathrm{m}^{-2}$ day $^{-1}$.

The observations were taken at the phenological development stages viz., 4 LS (LS, leaf stage), 8 LS, 12 LS, tasselling (TS), milk (MS) stage and at physiological maturity (PMS) in maize; at crown root initiation (CRIS), tillering (TILS), spike initiation (SIS), anthesis (AS), dough (DS) stages and at PMS in wheat; at branching (BS), flowering (FS), pod initiation
(PIS), pod filling (PFS) and at PMS in green gram. These growth stages were recorded when 50 per cent of the plants in individual plots reached a given phenological stage. LAI in three replicates was measured at different phenological stages for each crop, using Canopy Analyzer (CA 2000Li, Li-COR, USA). The LAD values were calculated on the basis of LAI and days taken for phenological stages, with the help of the standard formula given by Beadle (1985). Plant samples (three plants each for maize and green gram, and $1 \mathrm{~m}^{2}$ for wheat) were collected at each phenological stage, oven-dried to determine the total DM accumulation. The CGR, RGR and NAR values were computed on the basis of the dry matter obtained using the standard formulae given by Beadle (1985). Daily incidental solar radiation (SRD) was derived from the daily sun shine hour data recorded at the IARI weather station. To get the fraction of intercepted Photosynthetically Active Radiation (fPAR), the values of NDVI taken at each phenological stage were used in the formula $\mathrm{fPAR}=-0.29+1.50 \times$ NDVI (Pellegrini et al., 2020). The NDVI is the green seeker (Trimble, USA) value at a given stage calculated using the formula NDVI $=(R 774-R 656) /(R 774+R 656)$. Then the total solar radiation intercepted in terms of $\mathrm{MJ} . \mathrm{m}^{-2}$ day $^{-1}$ was estimated as fPAR $x$ daily total solar radiation. The SRD (MJ.m ${ }^{2}$. day $\left.^{-1}\right)$ intercepted by plant canopy was then multiplied with the leaf area duration $\left(\mathrm{m}^{2}\right.$ day) to get the integral of total solar radiation intercepted for a growth phase. Grain yield at standard moisture was determined by sampling from $1 \mathrm{~m}^{2}$ area at 2 places from the centre of undisturbed area of plots, with uniform plant population of each crop. Statistical analysis was performed using the SPSS software.

\section{RESULTS AND DISCUSSION}

\section{Relative growth rate (RGR; $\mathrm{g} \mathrm{g}^{-1}$ day $\left.^{-1}\right)$}

The RGR was influenced by FYM, N and P supply. Pooled analysis of the two years data showed that, peak RGR was attained at $8 \mathrm{LS}$ in maize, at SIS in wheat, and at FS in green gram. Application of recommended dose of NPK and sulphur significantly increased the RGR of maize (Harender et al., 2018). The RGR has shown different relationship with the mean temperature during growth, depending on the crop, development stage and season. The RGR of maize has shown peak coinciding with mean temperature of $29^{\circ} \mathrm{C}$ while temperatures below or beyond this caused a significant reduction in the RGR (Fig. 1). In case of wheat, the RGR was significantly high at mean temperature of $12-13^{\circ} \mathrm{C}$ and declined with increase in mean temperature. On the other hand, RGR in green gram did not show very specific relationship. However, it was generally high at temperatures of $35^{\circ} \mathrm{C}$. These indicate differential temperature optima for crops and subsequent effect on crop growth and development in terms of LAD, NAR and CGR. The values of RGR were highest for maize followed by green gram and wheat.

\section{Leaf area duration (LAD; $m^{2}$. day)}

Increase in the levels of FYM, N and P in maize, wheat and green gram showed a corresponding increase in the LAD of the crops (Fig 1). The two- and three-way interactions of FYM, N and P were observed to significantly increase the LAD over the control at different growth stages. The pooled analysis of the two years crops data showed that the LAD attained its peak at TS in maize, SIS in wheat and PFS in green gram. Combine application of FYM, N and 
Table 1: Grain yield and weather during the growing seasons of 2018-2020.

\begin{tabular}{|c|c|c|c|c|c|c|c|c|c|c|c|}
\hline Crop & $\begin{array}{l}\text { Year } \\
\text { (season) }\end{array}$ & $\begin{array}{c}\text { Grain } \\
\text { yield } \\
\left(\mathrm{Mg} \mathrm{ha}^{-1}\right)\end{array}$ & SD_GY & $\begin{array}{c}\text { Tmax } \\
\left({ }^{\circ} \mathrm{C}\right)\end{array}$ & SD_Tmax & $\begin{array}{l}\text { Tmin } \\
\left({ }^{\circ} \mathrm{C}\right)\end{array}$ & SD_Tmin & $\begin{array}{l}\text { Tavg } \\
\left({ }^{\circ} \mathrm{C}\right)\end{array}$ & SD_Tavg & $\begin{array}{c}\text { Solar } \\
\text { radiation } \\
\left(\mathrm{KJ} \mathrm{m}^{-2}\right. \\
\left.\text { day }^{-1}\right)\end{array}$ & $\begin{array}{c}\text { Precipitation } \\
(\mathrm{mm} / \text { day })\end{array}$ \\
\hline Maize & Year2 (K) & 6.05 & 1.92 & 32.2 & 0.21 & 23.2 & 0.30 & 27.7 & 0.24 & 13982 & 3.11 \\
\hline Wheat & Year1 (R.) & 4.66 & 0.27 & 26.0 & 0.30 & 10.8 & 0.32 & 18.4 & 0.28 & 12962 & 0.98 \\
\hline \multirow[t]{2}{*}{ G gram } & Year1 (S) & 0.89 & 1.37 & 40.1 & 0.23 & 26.6 & 0.52 & 33.3 & 0.36 & 24463 & 1.39 \\
\hline & Year2 (S) & 1.07 & 0.20 & 38.7 & 0.27 & 25.8 & 0.36 & 32.2 & 0.23 & 23567 & 2.31 \\
\hline
\end{tabular}

Tavg $=$ Average seasonal temperature, $\mathrm{SD}=$ Standard deviation, $\mathrm{K}=$ Kharif, $\mathrm{R}=$ Rabi, $\mathrm{S}=$ Summer

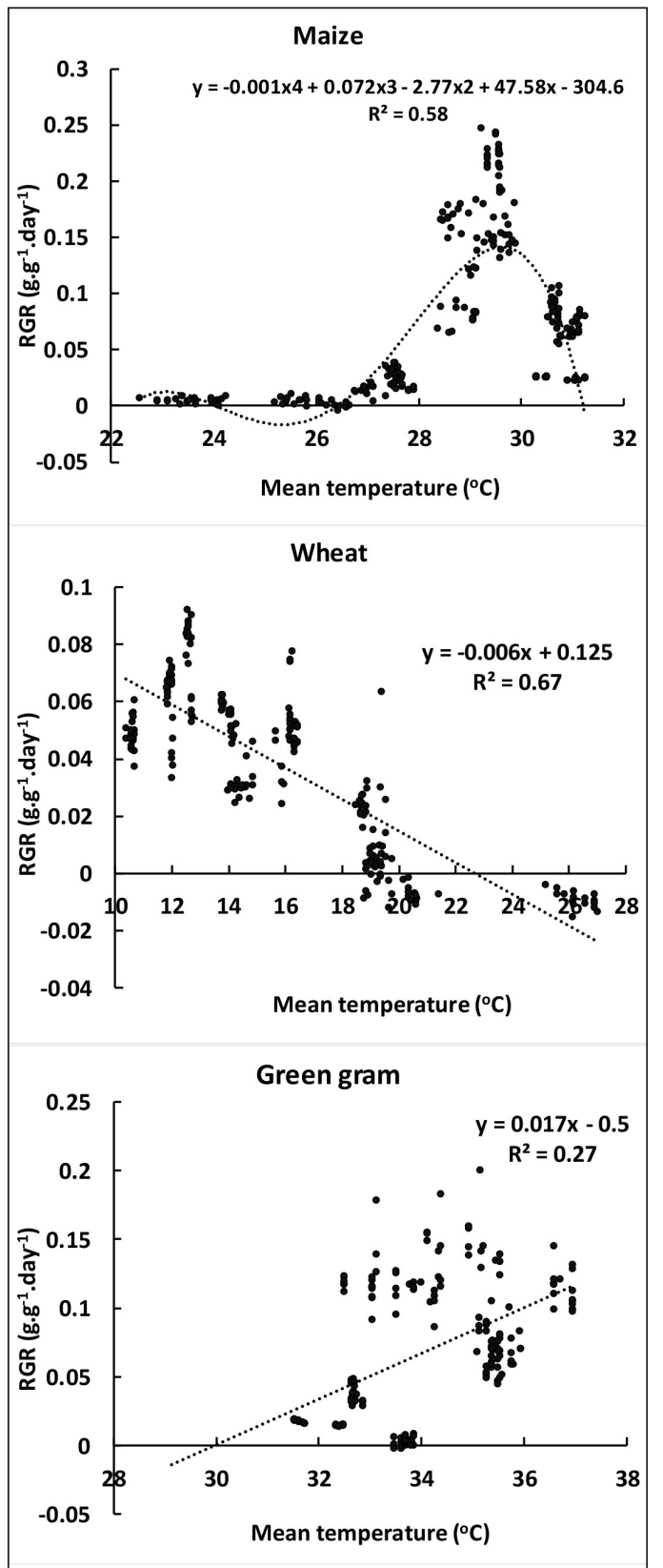

Fig. 1: Effect of mean temperature on relative growth rates of maize, wheat and green gram
$\mathrm{P}$ in different interactions $\left(\mathrm{FYM} \mathrm{N}^{*} \mathrm{~N}, \mathrm{P}, \mathrm{FYM}^{*} \mathrm{~N}, \mathrm{FYM} \mathrm{F}^{*} \mathrm{P}\right.$ and $\left.\mathrm{N} * \mathrm{P}\right)$ significantly increased LAD over the control. Increasing application of $\mathrm{N}$ fertilizer increased the LAD and shoot $\mathrm{N}$ concentration in wheat (Wang et al., 2017) and sufficient nutrient supply to the crops enabled assimilation of photosynthates for longer period.

\section{Net assimilation rate (NAR; gDW. $\mathrm{m}^{-2}$ leaf area. day $\left.\mathrm{y}^{-1}\right)$}

Generally, increase in the nutrient levels increased the NAR (data not shown). The NAR peaked at TS in maize, AS in wheat and at PIS in green gram, and then gradually declined towards physiological maturity. The NAR values were significantly influenced by the nutrient interactions and a positive residual effect of nutrients on succeeding green gram NAR is also noted. Combined applications of organic and chemical nutrients at higher levels increased CGR and NAR values during crops development (Din et al., 2021).

\section{Crop growth rate (CGR; $\mathrm{g} \mathrm{m}^{-2}$ day $\left.^{-1}\right)$}

The CGR attained its peak at TS in maize, AS in wheat and at PIS in green gram. Improvement in the CGR in green gram indicates significant residual effects of nutrients applied to preceding crops. Higher CGR is attributed to efficiency of leaf canopy to convert solar energy into dry matter. Treatments that had highest values of LAD also has higher CGR, indicating the efficiency of higher LAD in assimilating photosynthates and eventual conversion to dry matter. The persistence of leaf area growth is significantly influenced by the nutrient supply (Wasaya et al., 2017). Application of $\mathrm{N}$ fertilizer increased the CGR in maize by an average of 15 per cent in comparison to no nitrogen.

\section{Correlation between $L A D * S R D$ and $C G R$}

The correlation of peak LAD and SRD integral with CGR for the three crops was highly significant at peak growth period coinciding late vegetative phase in all three crops (Fig. 2). This indicates that the plants having higher LAD, as in case of plants receiving full nutrients, had also higher solar radiation interception eventually leading to higher CGR.

\section{Mean grain yield $\left(\mathrm{Mg} \mathrm{ha}^{-1}\right)$ and influence of weather variation in two years}

The mean grain yield of maize, wheat and green gram 


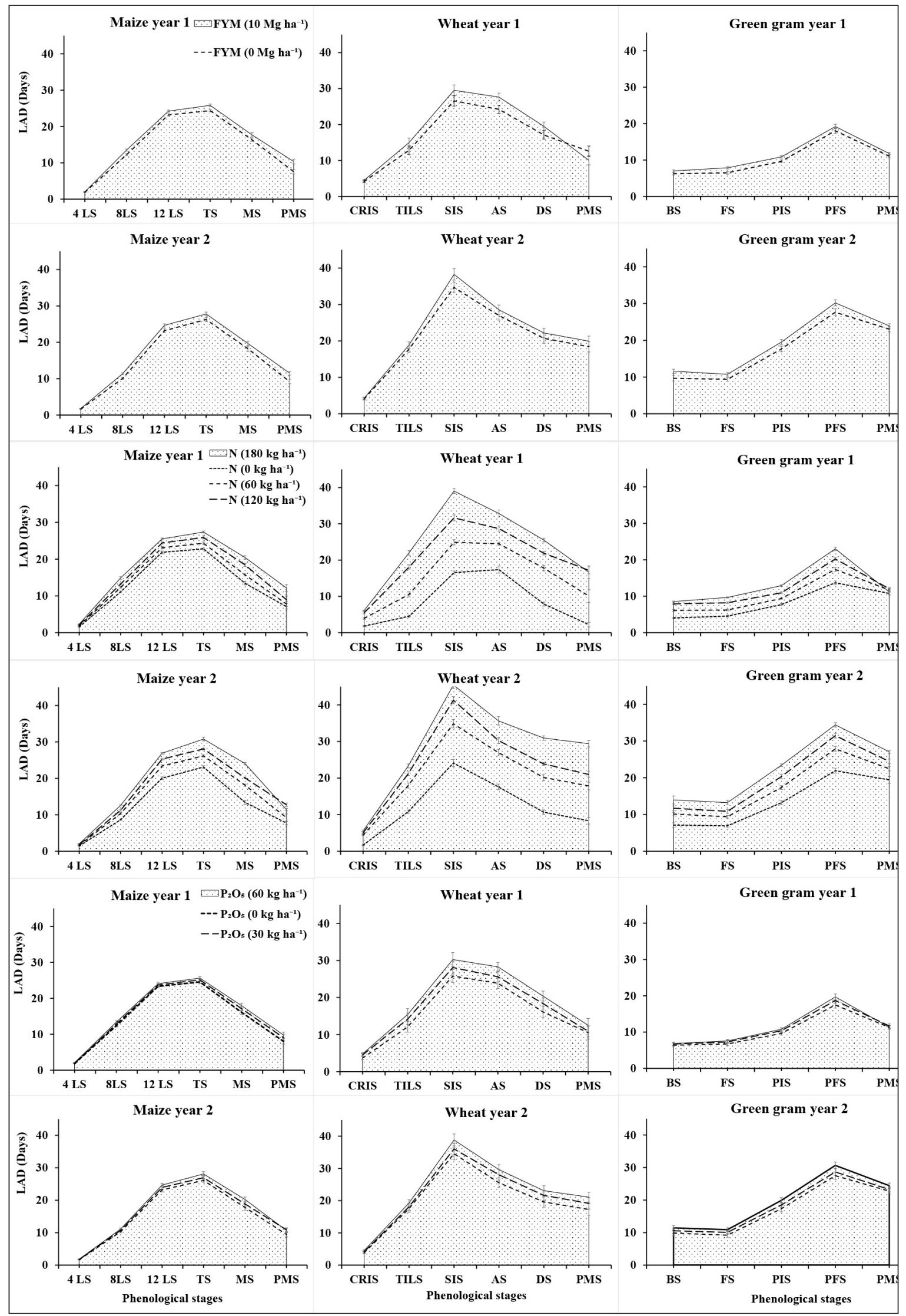

Fig. 2: Leaf area duration ( $\mathrm{m}^{2}$. days) of maize, wheat and green gram in 2018-19 and 2019-20 growing seasons as influenced by farmyard manure (FYM), nitrogen $(\mathrm{N})$ and phosphorus $(\mathrm{P})$ fertilization. 


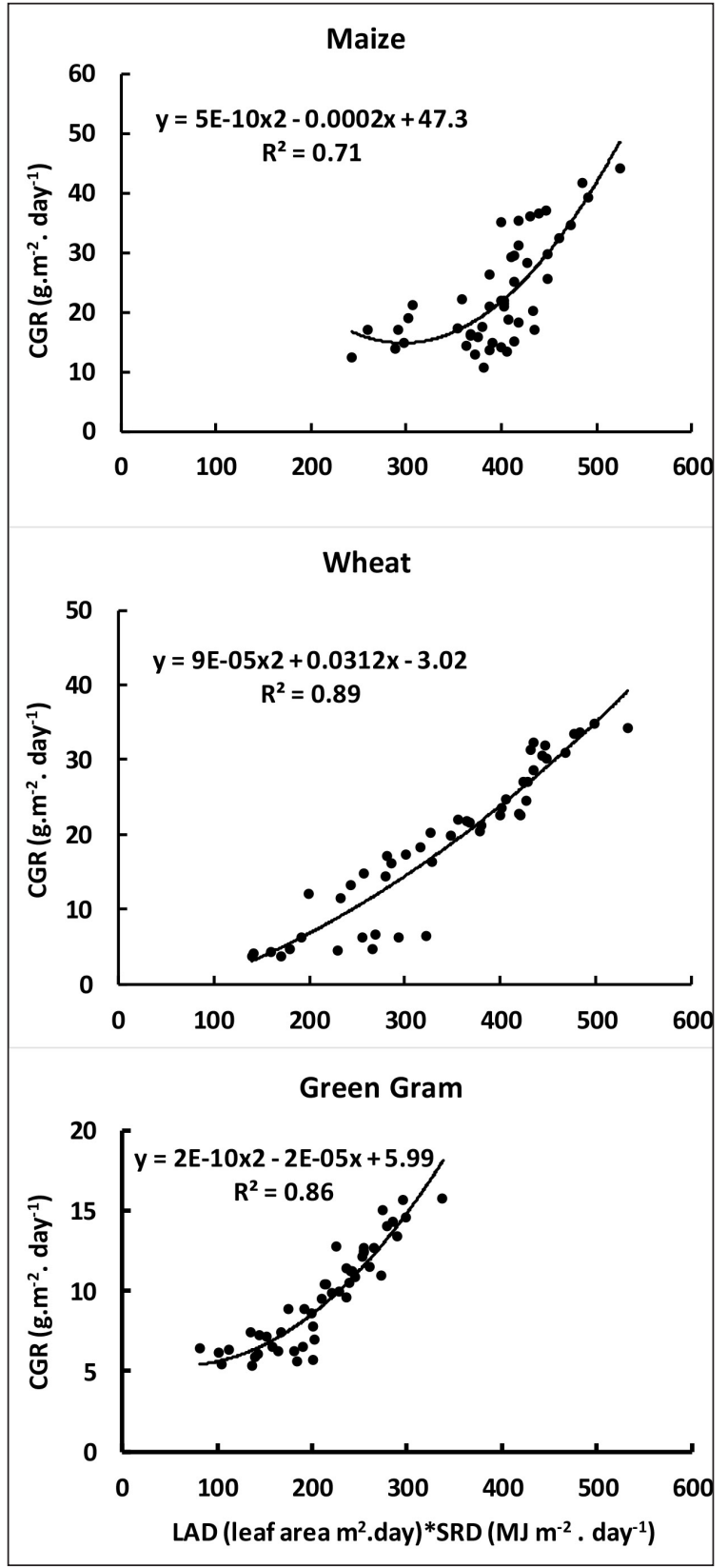

Fig. 3: Relationship of leaf area duration (LAD) and incidental solar light (SRD) levels with crop growth rate (CGR) at late vegetative stages of maize, wheat and green gram.

across treatments differed between two years. This indicated the effect of weather irrespective of the nutrient treatments (Table 1). During the first year, high seasonal mean maximum (by $1.3^{\circ} \mathrm{C}$ over year 2) and mean (by $0.4^{\circ} \mathrm{C}$ ) temperatures, with more variability (as higher standard deviation) and significantly high rainfall (about 2.5 times) contributed to reduced grain yield in maize, despite more incidence of solar radiation. In case of wheat, high variability in temperatures and less incidence of solar radiation lead to reduced yield during year two. In addition, from $5^{\text {th }}$ March, 2020 to $15^{\text {th }}$ March 2020, about $151 \mathrm{~mm}$ of rainfall occurred in 5 effective rainfall days with two events of 42.2 and $63.2 \mathrm{~mm}$. In green gram, high seasonal temperatures $\left(40.1 / 26.6^{\circ} \mathrm{C}\right)$ with high variability led to yield reduction in year one as compared to year two. The results indicated that variation in yield across years due to weather fluctuations, irrespective of treatments, was about 16.7 per cent in maize (kharif), 7.93 per cent in wheat (rabi) and 16.8 per cent in green gram (summer).

\section{Correlation of LAD, CGR, RGR and NAR with mean grain yield}

Further analysis indicated that correlations between mean grain yield and peak LAD, CGR, RGR and NAR were at different magnitudes across crops (Fig 4). Results showed that, all the growth indices at maximum level had positive association with the grain yield of respective crop. Grain yield in maize showed a strong linear relationship with LAD and CGR, while it was moderate with RGR and weak with NAR. Wheat yield had strong linear relationship with LAD, CGR and RGR and moderate with NAR. Green gram yield on the other hand showed positive but very weak relationship with all the growth indices. Wheat grain yield showed a significant correlation with CGR (Din et al., 2021). The LAD had significant positive correlation with grain yield indicating the crops with optimum LAI for longer period had opportunity to assimilate more photosynthates as indicated by its positive correlation with CGR when used in integral with SRD. Correlation of NAR with yield is low indicating even at similar NAR, crop with higher LAD and solar radiation integral can assimilate more photosynthates to cause higher CGR. The CGR is positively correlated with yield indicating that higher accumulation of biomass leading to reproductive phase enables higher yield, provided non-stress periods exist in reproductive and grain filling phase.

\section{CONCLUSIONS}

Based on the present study, it can be concluded that joint application of organic and inorganic nutrients enhanced the CGR and NAR in maize and wheat, with a positive residual effect on green gram. The RGR was at peak in maize (kharif) at $29^{\circ} \mathrm{C}$ and in wheat (rabi) at $12-13^{\circ} \mathrm{C}$, while in green gram (summer) the peak was at $35^{\circ} \mathrm{C}$. The LAD, CGR, RGR and NAR growth indices have positive linear relationships with grain yield, with varying degrees of importance. Crops with higher LAD and SRD integral had positive correlation with the CGR and grain yield. Further, slightly higher NAR in combination with LAD and SRD can significantly contribute to overall performance of crops. Results indicated that variation in yield across years due to weather fluctuations, irrespective of treatments, is about 16.7 per cent in maize (kharif), 7.93 per cent in wheat (rabi) and 16.8 per cent in green gram (summer) during two years of experimentation.

\section{ACKNOWLEDGEMENTS}

The authors would like to express their gratitude to the Post Graduate School, ICAR-Indian Agricultural Research InstituteNew Delhi for providing facilities to first author; and Department of Science and Technology (DST)-MRDP project-Ministry of Science and Technology, Government of India for supporting the research to the corresponding author. Partial funding by NICRA projected is also duly acknowledged.

Conflict of Interest Statement: The author(s) declare(s) that there is no conflict of interest. 


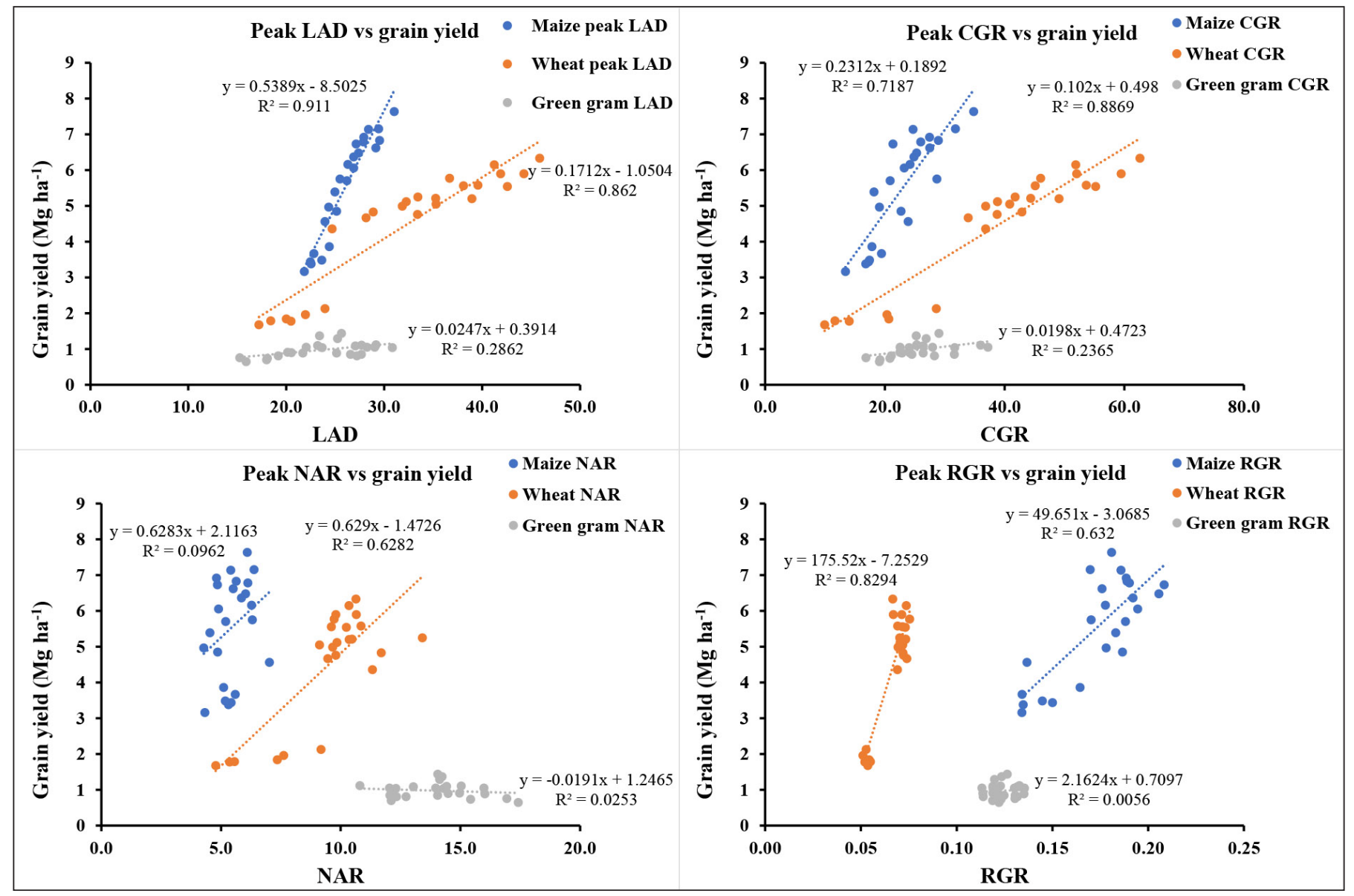

Fig. 4: Correlation of mean peak LAD, CGR, NAR and RGR with mean grain yield of maize, wheat and green gram.

Disclaimer: The contents, opinions, and views expressed in the research article published in the Journal of Agrometeorology are the views of the authors and do not necessarily reflect the views of the organizations they belong to.

Publisher's Note: The periodical remains neutral with regard to jurisdictional claims in published maps and institutional affiliations.

\section{REFERENCES}

Beadle, C. L. (1985). Plant Growth Analysis. In Techniques in Bioproductivity and Photosynthesis (2nd Edition). Pergamon Press Ltd. https://doi.org/10.1016/b978-0-08-031999$5.50012-1$

Din, I., Khan, H., Ahmad Khan, N., and Khil, A. (2021). Inoculation of nitrogen fixing bacteria in conjugation with integrated nitrogen sources induced changes in phenology, growth, nitrogen assimilation and productivity of wheat crop. J. Saudi Soc. Agril. Sci., https://doi.org/10.1016/j.jssas.2021.05.008.

Harender, Singh, S., Kavinder, Malik, K., and Rathi, N. (2018). Impact of Different dose of Plant Nutrient in Terms of Growth, Quality, Yield and Economics of Maize (Zea mays L.). Int. J. Plant \& Soil Sci., 21(5): 1-8.

Hazra, K. K., Nath, C. P., Singh, U., Praharaj, C. S., Kumar, N.,
Singh, S. S., and Singh, N. P. (2019). Diversification of maize-wheat cropping system with legumes and integrated nutrient management increases soil aggregation and carbon sequestration. Geoder., 353: 308-319.

Kar, G., and Kumar, A. (2016). Radiation utilization efficiency and surface energy exchange of winter maize (Zea mays L.) under different irrigation regimes. J.Agrometeorol., 18(2):190-195.

Kavinder, Hooda, V. S., Malik, Y. P., . Devraj, Harender and Kavita. (2019). Effect of farm yard manure and nitrogen application on growth and productivity of wheat under long term experimental conditions. Curr. J. Appl. Sci. \& Tech., 35(4): $1-7$.

Mishra, S. K., Shekh, A. M., Pandey, V., Yadav, S. B., and Patel, H. R. (2015). Sensitivity analysis of four wheat cultivars to varying photoperiod and temperature at different phenological stages using WOFOST model. J. Agrometeorol., 17(1): 74-79.

Mukherjee, J., Yadav, B., Sehgal, V. K., Das, D. K., Krishnan, P., and Dhakar, R. K. (2020). Radiation dimming induced modifications in radiation utilization of wheat (Triticumaestivum) crop. J. Agrometeorol., 22(3): 330-336.

Naresh Kumar S. and C.P.Singh (2000). Nitrogen use efficiency in maize (Zea mays L.): Influence of nitrogen sources, and 
doses and crop seasons. J. Plant Biol., 27 (2): 161-169.

Özalkan, Ç., Sepetoğlu, H. T., Daur, I., \& Şen, O. F. (2010). Relationship between some plant growth parameters and grain yield of chickpea (Cicer arietinum L.) during different growth stages. Turkish J. Field Crops, 15(1): 79-83.

Pellegrini, P., Mariano, C.C, Di Bella, C.M., Piñeiro, G., Sadras, V.O. and Oesterheld, M (2020). Simple regression models to estimate light interception in wheat crops with Sentinel-2 and a handheld sensor. Crop Science, DOI: 10.1002/csc2.20129

Shekhawat, K., and Shivay, Y. S. (2012). Residual effects of nitrogen sources, sulfur and boron levels on mungbean (Vigna radiata) in a sunflower (Helianthus annuus)-mungbean system. Arch. Agron. Soil Sci., 58(7): 765-776.
Tovihoudji, P. G., Akponikpè, P. B. I., Agbossou, E. K., and Bielders, C. L. (2019). Variability in maize yield and profitability following hill-placement of reduced mineral fertilizer and manure rates under smallholder farm conditions in northern Benin. Field Crops Res., 230: 139-150.

Wang, X., Ye, T., Ata-Ul-Karim, S. T., Zhu, Y., Liu, L., Cao, W., \& Tang, L. (2017). Development of a critical nitrogen dilution curve based on leaf area duration in wheat. Front. Plant Sci., 8: $1-11$.

Wasaya, A., Tahir, M., Ali, H., Hussain, M., Yasir, T. A., Sher, A., Ijaz, M., and Sattar, A. (2017). Influence of varying tillage systems and nitrogen application on crop allometry, chlorophyll contents, biomass production and net returns of maize (Zea mays L.). Soil and Tillage Res., 170: 18-26. 